\title{
Ouderen blijven steeds langer doorwerken
}

\author{
HANNA VAN SOLINGE
}

Mede door wijzigingen in de pensioenregelgeving blijven ouderen steeds langer doorwerken. Dat is zichtbaar in de zogenaamde participatiecijfers. De arbeidsparticipatie geeft aan welk deel van de bevolking deelneemt aan het arbeidsproces. In 2007 was $35 \%$ van de 60-65jarige mannen en $19 \%$ van de vrouwen in die leeftijdsgroep werkzaam. In 2015 was dat aandeel spectaculair gestegen tot $60 \%$ bij de mannen en $39 \%$ bij de vrouwen. Als gevolg van het verslechterde economisch klimaat en de beperktere mogelijkheden om bij reorganisaties gebruik te maken van pre-pensioenmogelijkheden, steeg in diezelfde periode ook de werkloosheid onder ouderen. Het werkloosheidpercentage verdriedubbelde bij mannen van $2,2 \%$ tot $6,7 \%$ en bij vrouwen van I,I $\%$ tot $3,7 \%$.

\section{Netto arbeidsparticipatie en werkloosheid van 60-65-jarigen (2007-2015)}
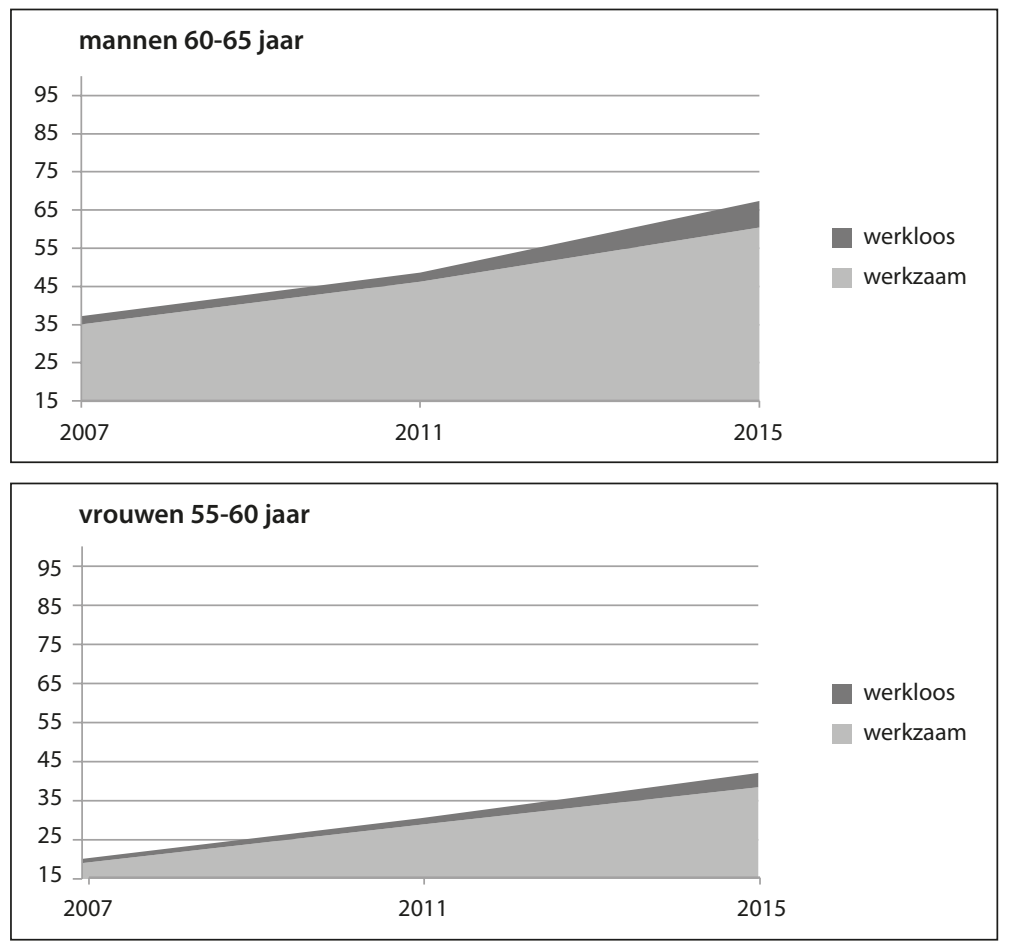

De netto arbeidsparticipatie (onderste gebied) geeft aan hoeveel procent van de beroepsgeschikte bevolking ook daadwerkelijk een betaalde baan heeft. Werklozen worden hierin dus niet meegeteld. 